\title{
$P$ and/or E: That Is (Still) the Question (Or Is It?)
}

\section{Collection Development in a Post-pandemic World}

Steve Perisho, Seattle Pacific University

Juliana Morley, Biola University

David Schmersal, Austin Presbyterian Theological Seminary

\begin{abstract}
While the question of whether to choose the print and/ or electronic format of a given title is certainly not new, the circumstances in which we are making such decisions have changed, prompting many of us to reconsider collection development priorities. Three librarians share their observations in answering three interrelated questions: (1) How did limited access to print collections affect student research behavior and faculty expectations in the course of the pandemic? (2) What strategies have libraries adopted to provide access to print-exclusive content? and (3) What criteria do they use in determining whether print or digital format is more suitable for a given title? While electronic resources certainly offer advantages, those who make and/or inform collection development decisions would do well to consider potential pedagogical implications of format as well as the ways in which providing access to electronic format exclusively may affect our ability to serve library patrons beyond the seminary community, including alumni and local clergy.
\end{abstract}

\section{DESCRIPTION}

While the question of whether to choose the print and/or electronic format of a given title is certainly not new, the circumstances in which we are making such decisions have changed, prompting many of us to reconsider collection development priorities. If, as seems likely, the changes accelerated by the COVID-19 pandemic-offering many if not all classes online, enabling many students and staff to work remotely-represent a watershed, prioritizing e-books and other electronic resources is a logical response. Of course, not every- 
thing is available electronically, so how can we make print-only sources available to students who do not have physical access to the library? Conversely, what about our print collections? When and why might one still prefer print, even when it is not substantially cheaper, or the only option? How might we continue to serve patrons who only have access to our print collections, such as alumni and local clergy, if we are acquiring most of our new resources electronically? Here follows a guided discussion of these and related questions. A panel of our colleagues share their strategies for providing access to print-exclusive content, as well as their decision-making processes, identifying criteria they use in determining whether print or digital format is more suitable for a given title and sharing factors that inform such decisions. (In the live session, time was also reserved for our participants to share their own experiences and observations, as well as questions, for the benefit of all in the session.)

\section{INITIAL REMARKS:}

As we have been forced to realize that online theological education and remote work are not only possible, but have some advantages, this will doubtless affect the kinds of materials we acquire and the ways in which we make them available. Where, then, do our print collections fit into this?

To guide our consideration of this larger question, we structured our discussion around three pertinent sub-questions:

1) What changes have you noted in patrons' information-seeking behavior over the course of "COVID-tide"?

2) How have you adapted your services to make your print collections available to patrons while the library has been closed, and to what extent do you anticipate continuing such adaptations?

3) To the extent that you have a say in acquisitions decisions, what factors do you consider in determining whether to select print or electronic format for a given title, and how might changes wrought by the pandemic alter the relative weight of these factors going forward? 


\section{(1) WHAT CHANGES HAVE YOU NOTED IN PATRONS' INFORMATION-SEEKING BEHAVIOR OVER THE COURSE OF “COVID-TIDE”? (STEVE PERISHO)}

The following observations are based on five academic quarters at Seattle Pacific University during the pandemic.

During the 2020 Spring and Summer terms the print-based General and Reference collections were unavailable except via a limited amount of formal and informal liaison-mediated scanning. Consortial borrowing was likewise unavailable, though we were able to use InterLibrary Loan for articles (though not many books) inaccessible via SPU systems. An even heavier emphasis was placed on the purchase of e-books, as well as the emergency collections made available by others. Although consortial and ILL along with a mediated form of General Collection borrowing had all been largely restored in time for the opening of Autumn Quarter 2020 (all via contactless pickup), the legacy or print-based portion of the Reference Collection remained inaccessible. That and the prohibition of stack-browsing in general aside, this represented an almost complete return to the status quo ante-indeed, a kind of enhancement of it, given that the chapter-scanning service aforementioned, instituted by the Spring of 2020, was completely new to SPU. And yet requests for reference and research support in Theology were-just as over ATLANTIS and other Atla listservs, too-all down.

As for remote teaching and assignment support, I offered that in three main areas over the course of the past five quarters: Philosophy; undergraduate Gateway and Seminary Core courses in Christian Scripture; and the disciplinary Writing courses taught by our theologians.

The Seminary Core courses, but especially the undergraduate Gateway courses in Christian Scripture, have long expected a lot of our students exegetically, and by extension, therefore, demanded a heavy use of the major tools, some of which (e.g., the lexica, the theological wordbooks, and some of the Bible dictionaries and encyclopedias above all) are unavailable here in electronic form. This remote inaccessibility - which is due to (1) a Library-wide policy against the acquisition of software that must be restricted to a limited number of "stations," "seats," or "labs" as well as (2) the fact that neither the School of Theology nor the Library has chosen to underwrite individual subscriptions-has resulted for years and years in a very 
heavy use of the Reference Collection, in the vicinity of which SPU undergraduates and seminarians all tend to camp out for days at a time. ("Who said print is dead?")

With the closure of the Reference Collection to all but staff, not to mention a shift to online instruction that resulted in fewer (and evermore inconvenient) trips to campus, this, of course, all went away. During the pandemic, professors, who, stressed themselves, had also been encouraged to go easy on their students have, as a consequence, mined their own personal software packages, supplying their students with the entries that they would otherwise have scanned for themselves (a problematic practice at best), and/or advertised the scanning services offered by the ILL Department. They also seem to have lowered their expectations considerably and not pushed their students hard into the search for scholarship, as before.

In response, I have double-purchased e-commentaries in droves, offered to drive down to the Library and scan, and asked students to share their search screens, with very positive results (though I cannot speak to follow-through because I do not grade student papers). A few students, and fewer each quarter of the pandemic, have taken me up on the offer to scan, but without, of course, having done any of the pedagogically important preliminary work that access to print-based Reference would have allowed, as in former times.

In working with students and faculty in WRI 1100, I have continued to teach research, while also letting students know about the placement of scanning requests, contactless pickup, and consortial and ILL borrowing. I have scanned materials and mounted entry lists to facilitate the placement of formal scanning requests from works of reference (here is an example from our freshman course in The Christian Faith: https://spu.libguides.com/c.php?g=1043593\&p=7570675). As with the Gateway and Core Courses in Scripture, a few students, and (again) fewer each quarter of the pandemic, have availed themselves of my offer to help them individually. The vast majority have not sought any help whatsoever. Though I neither see nor grade the final submissions of any of them, my presumption is that the employment of SPU, consortial, and ILL materials, online as well as on paper, is-as I feared at the outset it would be (along with faculty standards and requests for research assistance)-way down.

Nor are these trends limited to courses in the humanities. A colleague in science and medicine has observed that even before the pandemic, students exhibited a sharp decline in willingness to 
use print sources, an inability to navigate online sources effectively, and a decline in the ability to distinguish between types of online sources, and therefore to cite them properly. That's far more of an endorsement of "providing access to electronic format exclusively" than-as my own comments so far would indicate-I am (or anyone in the humanities ought to be) ready to make, but contains also some observations of interest.

Drawing upon these observations, I offer the following takeaways: First, access to scholarship available only on paper remains-for the time being, at least-crucial to courses in theology and religious studies that happen to be tied to research (let alone, of course, research itself). However, for this to remain the case, faculty must maintain the expectation of rigorous scholarship on the part of their students, and librarians must find ethical and sustainable ways to provide and facilitate access to print scholarship, in addition to continuing the shift to electronic access. This is so because the changes in information-seeking behavior that I've seen, speaking anecdotally, have been, despite our efforts here in Seattle, largely reductive in nature. They seem to have involved that decline in standards and performance (and therefore the need for a library) that I suspected would be the (also long-term?) result of the (arguably overly draconian?) response to the pandemic.

\section{(2) HOW HAVE YOU ADAPTED YOUR SERVICES TO MAKE YOUR PRINT COLLECTIONS AVAILABLE TO PATRONS WHILE THE LIBRARY HAS BEEN CLOSED, AND TO WHAT EXTENT DO YOU ANTICIPATE CONTINUING SUCH ADAPTATIONS? (JULIANA MORLEY)}

Biola University Library serves approximately 6,000 students and 150 programs. The library currently has more titles available electronically than in print. We are primarily a residential campus. According to survey results, $97 \%$ of our students said they use the library in person, and $68 \%$ said they prefer to contact a librarian at the reference desk. When the pandemic hit, our faculty were very concerned about how their students would access our print collection, especially the biblical studies and theology material. I assured them that our online collections are very strong, but if they needed a print resource, there will be ways to access it. I also reminded them 
that we have been supporting online programs and students for many years, and that librarians are still here (remotely) to help them.

Like many of our colleagues, during COVID-19, we provided access to our circulating print collections through a pickup service by which students, faculty, and staff would request items online and pick up materials at the entrance to the library. We also made our reference and reserves material available to students by appointment at the entrance to the library. In addition, we launched a mailto-home service, which allowed students to request a book to be mailed to their home. We also augmented our ILL services to include a document delivery service, by which scans of journal articles and book chapters from the print collection could be requested.

The last thing we tried to market was our reciprocal borrowing programs. Even during "normal” times, reciprocal borrowing programs were often underutilized because our students did not know about them. These programs allow our online students to gain access to print collections and to physical study spaces near them. They can also gain access to biblical and theological material that is only available in print, as well as access to special collections and public library material. While most libraries in California were closed, libraries in other states may have been open during this time.

Students and/or faculty currently have access to 250 institutions through the following reciprocal borrowing agreements:

- LINK+ (consortium of libraries in CA and NV)

- ACL (U.S. and Canada)

- Atla (U.S. and Canada)

- SCATLA (theological libraries in CA)

- SCELC (mostly CA)

- Other agreements (local institutions)

We have created a Reciprocal Agreements Chart to allow our students to search for libraries by location and easily apply for access: https://libguides.biola.edu/reciprocalagreements

(3) TO THE EXTENT THAT YOU HAVE A SAY IN ACQUISITIONS DECISIONS, WHAT FACTORS DO YOU CONSIDER IN DETERMINING WHETHER TO SELECT PRINT OR ELECTRONIC FORMAT FOR A GIVEN TITLE, AND HOW MIGHT CHANGES 


\section{WROUGHT BY THE PANDEMIC ALTER THE RELATIVE WEIGHT OF THESE FACTORS GOING FORWARD? (DAVID SCHMERSAL)}

Acquisitions was only recently added to my responsibilities, so I am not drawing on a lot of experience. Still, even a brief time has offered a sense of the many factors that go into such decisions, and the pandemic has, if anything, made this more complex. Like many of you, initially we concentrated on acquiring as much electronically as possible. This continued and indeed accelerated a trend toward emphasizing e-books that began when we began planning for the renovation of the library, knowing that a bulk of our collections would be inaccessible for about two years. At the same time, as I was making more collection development decisions, I recognized that in some cases print may still be a better-or the only-option. I developed a mental flow chart, resembling the flow chart below, to help me weigh the relative merits of e-book versus print for a given title, based on the following factors:

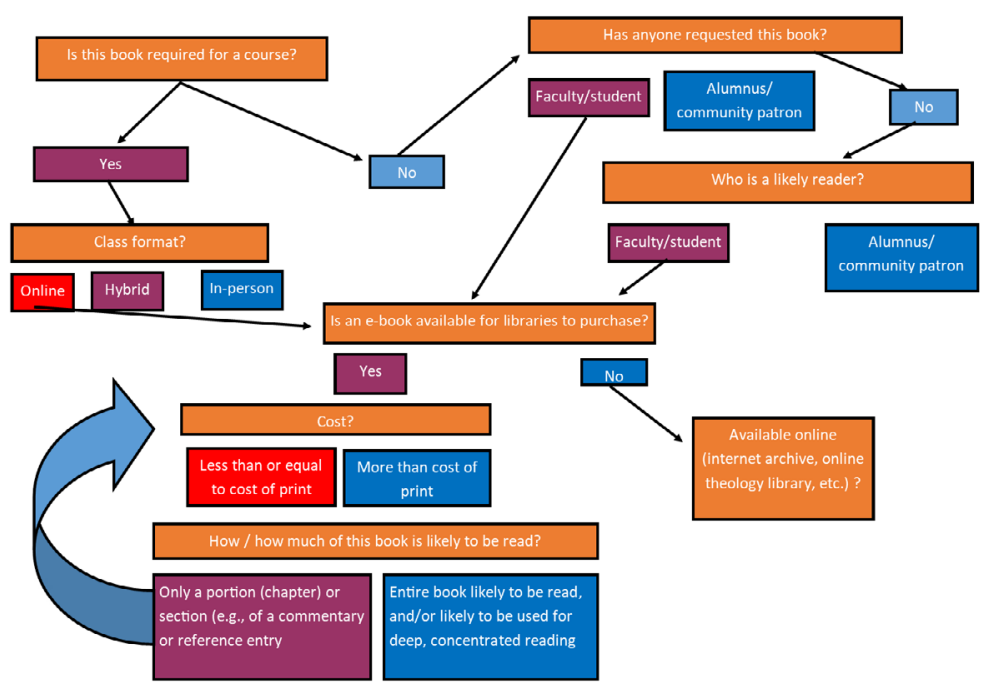




\section{AVAILABILITY}

The fact remains that not everything is available for libraries to purchase as e-books. In our field of religion and theology, with five thousand years' worth of back titles, this is not likely to change entirely, though it may change for a given title, which can make it a point to consider. It is also a point that requires careful, nuanced communication, since it does not really help to tell a faculty member that something is not available as an e-book when she has it on her Kindle.

\section{COST}

This is an obvious factor, but not always as straightforward as one might think. While in many cases (though, not always) the print is less expensive, this does not always make it more cost-effective, since an e-book that allows unlimited users can equal the cost of buying only a second physical copy. Thus, cost must also be held in dialogue with another factor: use.

USE

Use (or anticipated use) is another complex factor. First, there is the question of who is likely to use this book. Since meeting the research and educational needs of our students, faculty, and staff is our primary directive, discerning and anticipating these needs must be our priority; this becomes even more vital, and complicated, as more students, from varied backgrounds and in diverse locations, avail themselves of the options afforded by online theological education.

At the same time, while our students, faculty, and staff most certainly are our core constituency and it thus makes sense to privilege them in acquisitions decisions, there are important reasons to consider the needs of community patrons and alumni, who often do not have off-campus access to e-books: (a) Making our collections, specifically our print collections, accessible to our communities, to local clergy and others, aligns with our institutions' missions, whether it be serving the church as a seminary or serving the community as a university. (b) It is a matter of hospitality, of making at least some of our collections accessible to the wider community and thus serving as a good public-facing "face" for our institutions. (c) Being hospitable and accessible toward the wider community 
is not only a good thing to do, it is also in our best interest to do so-alumni and community members are more likely to support an institution that is able to loan them a copy of the commentary they need for a Sunday school class the next day. Making our collections accessible to local clergy also creates a sense of good will toward our schools, and such good will might just be enough to incline clergy to recommend our school to parishioners and congregants who want to pursue theological education or attend seminary. Thus, titles that may appeal to local clergy and other community patrons are an important, if secondary, factor to consider.

Second, there is the question of whether anyone is asking for this title, and if so, for what purpose, i.e., is a faculty member asking us to purchase this book for his or her own research? Is this a course reserve and if so, is the course being offered on campus or online? If a given book is required reading for a course, and thus likely to be a high-demand item, it is probably more cost-effective to purchase a UU e-book, even though it is more expensive than one copy of the print. On the other hand, if a faculty member would like a book for his or her own research, unless he or she is likely to use it as a required text in a future course, a 1U copy or print should suffice.

Third, there is the question of how sustainable demand is likely to be. A professor is always going to assign Augustine's Confessions for some class at some point, and given the fact that some of our students still prefer to read books in print, it makes sense to offer such books in both formats, if possible. But what about books on hottopic contemporary issues? How many books on 9/11 have you circulated in the last few years? How many have you weeded? E-books may be a better option for books that are likely to be in high demand, but for a short time. The shelf space I save in the long term may be worth the few extra dollars I would pay for an e-book on COVID19 that I would have to weed in ten years or so (while hoping that someone will keep an archival copy for the sake of future researchers, which brings up the question of preservation, for another time).

Fourth, there is the question of how much of a given book is likely to be used. For example, if it is likely that students (and others) will only need one essay out of The Oxford Handbook of XYZ, and I can scan said chapter from the print, and the print is significantly cheaper, it probably makes sense to choose the print.

Finally, there is the pedagogically significant question of whether print can be more conducive for sustained, concentrated reading. 
While time and space preclude an in-depth consideration of this question here, I have heard such sentiments echoed by students who express appreciation for the fact that a print book does not ding every time they get an email.

Moreover, choosing print or electronic format, and the way we use this format, can have pedagogical implications. Many online and electronic resources are based on a print analogy (division into volumes, page numbers), and students who are unfamiliar with print may find navigating electronic sources challenging. As another example, mutatis mutandis, when I use Accordance it is so easy to see the parsing information for a given Greek word, that I find myself becoming lazy and not even trying to discern the lexical form. This does not mean I do not, or should not, use Accordance, but that I need to be aware of how I am using it and whether it best serves my purpose in studying, i.e., am I preparing a sermon or trying to retain at least some of the Greek grammar I learned in seminary.

I hope it is apparent from what has preceded, but to make it clear, I in no way mean to suggest a rejection of e-books. I have and will continue to read e-books, especially audiobooks, just as I have continued, and will continue, to read print. For the foreseeable future, I expect the same will be true of our libraries. But I hope that what we have presented here at least suggests that print should remain a viable option when making acquisitions decisions. 